\title{
Hyperthermophilic Archaea and Bacteria Occurring within Indonesian Hydrothermal Areas
}

\author{
G. HUBER, R. HUBER, B. E. JONES', G. LAUERER, A. NEUNER, A. SEGERER, K. O. STETTER*, \\ and E. T. DEGENS ${ }^{2}$ \\ Lehrstuhl für Mikrobiologie, Universität Regensburg, 8400 Regensburg, Germany \\ 1 Gist-Brocades, Delft, The Netherlands \\ 2 previously in: Geologisch-Paläontologisches Institut, Universität Hamburg, 2000 Hamburg, Germany
}

Received February 20, 1991

\begin{abstract}
Summary
From 85 samples taken during cruise $45 \mathrm{~B}$ of the R/V SONNE within the Sunda Arc subduction zone and from solfatara fields in Java, thermophilic and hyperthermophilic archaea and bacteria were isolated. The archaea were found to belong to the genera Methanobacterium, Methanolobus, Methanosarcina, Acidianus, Thermoproteus, Desulfurococcus, Thermoplasma, Thermococcus and a so far unknown thermoacidophilic continental metal mobilizer. All 7 Thermoplasma isolates were found to represent a new genotype so far only found in Indonesia. The extremely thermophilic bacterial isolates are a new species of Thermotoga and a novel strict anaerobe, thriving by $\mathrm{H}_{2} / \mathrm{NO}_{3}{ }^{-}$autotrophy.
\end{abstract}

Key words: Archaca - Thermoplasma - Thermophilic - Solfataras - Nitrate.

\section{Introduction}

The most extremely thermophilic organisms known up to now belong to the Archaea (previously: archaebacteria), the third domain of life besides the Bacteria and the Eucarya (Woese et al., 1978; Woese et al., 1990). These hyperthermophiles are the archaeal sulfur metabolizers and some methanogens, growing optimally at temperatures above $80^{\circ} \mathrm{C}($ Stetter, 1982; Stetter, 1986; Burggraf et al., 1990; Stetter et al., 1990). Thermotoga maritima and the closely related Thermotoga neapolitana are the only bacterial hyperthermophilic species known with optimal growth at $80^{\circ} \mathrm{C}$ (Huber et al., 1986 b; Jannasch et al., 1988; Windberger et al., 1989). Thermotoga represents the deepest phylogenetic branch-off within the bacterial domain (Huber et al., 1986 b; Woese, 1987; Woese et al., 1990). Due to their exceptional position in the evolution of life and their outstanding cellular properties, hyperthermophiles are of great interest for microbiology and biotechnology.

Different hyperthermophilic archaea have been isolated from continental and submarine hydrothermal systems at the Azores, East Pacific Rise, Iceland, Italy, Japan, Poly-

\footnotetext{
* Corresponding author
}

nesia, Yellowstone National Park (USA), and New Zealand (Brock, 1978; Stetter and Zillig, 1985; Stetter, 1986; Stetter et al., 1987; Huber et al., 1990). Since hydrothermal biotopes are widely dispersed and hyperthermophiles are unable to grow at normal environmental temperatures, the question concerning dispersion arises. Although very few systematic studies on the distribution of hyperthermophiles have been carried out up to now, there is evidence for the existence of an endemic group: The Methanothermaceae have so far only been found in the southwest of Iceland (Lauerer et al., 1986). During the $\mathrm{R} / \mathrm{V}$ SONNE 45B cruise in Indonesia within marine areas of active volcanism along the Sunda Arc subduction zone and at solfatara fields in Bali and Java, attempts were made to address the following points: (a) the existence of novel hyperthermophilic archaea and bacteria in Indonesia, (b) the distribution of hyperthermophilic archaea within Indonesian hydrothermal systems and solfatara fields, (c) the dissemination of hyperthermophilic archaea between different hydrothermal systems through cold sea water, (d) the survival of hyperthermophiles in cold deepsea sediments. Here we report on the first results of our screening program. 


\section{Materials and Methods}

Strains. Acidianus infernus (DSM 3191), Pyrococcus furiosus (DSM 3638), Thermococcus celer (DSM 2476), Thermococcus litoralis (DSM 5473), Thermoplasma acidophilum (DSM 1728), Thermoplasma volcanium (DSM 4299), Thermotoga maritima (DSM 3109), and Thermotoga neapolitana (DSM 4359) were obtained from the Deutsche Sammlung von Mikroorganismen und Zellkulturen (DSM, Braunschweig-Stockheim, FRG).

Culture conditions. Strictly anacrobic organisms were cultured by following the anaerobic technique described by Balch et al. (1979). Methanobacterium, Methanosarcina and Methanolobus isolates were obtained after enrichment and plating on media described (Balch et al., 1979; König and Stetter, 1982). For plating, the media were solidified by $2 \%(\mathrm{w} / \mathrm{v})$ agar. If not mentioned otherwise, Thermococcus celer, Thermococcus litoralis, Pyrococcus furiosus and Thermococcus-like isolates were grown on "SME" medium supplemented with $0.1 \%(\mathrm{w} / \mathrm{v})$ yeast extract and $2.5 \%(w / v) S^{\circ}$ (Stetter et al., 1983). Thermotoga maritima, Thermotoga neapolitana and the Thermotoga-like isolates were grown as described (Huber et al., 1986 b; Windberger et al. 1989). Acidianus infermus and Acidianus-like isolates were grown anaerobically at $\mathrm{pH} 2$ in the presence of $\mathrm{H}_{2}$ and $\mathrm{S}^{\circ}$ or aerobically on $\mathrm{S}^{\circ}$ in Allen's medium (Allen, 1959; Segerer et al. 1986 a). Sulfolobus-like isolates and the metal mobilizers were enriched and isolated aerobically at $\mathrm{pH} 2$ in Allen's medium ( $\mathrm{Al}$ len, 1959), supplemented with $S^{\circ}$ or ore mixture G1 (Huber et al., 1986 a). Thermoproteus and Desulfurococcus-like isolates were enriched and grown anaerobically at $\mathrm{pH} 5.5$ in Allen's medium (Allen, 1959) supplemented with $0.1 \%$ (w/v) yeast extract, $0.1 \%$ $(\mathrm{w} / \mathrm{v})$ peptone and $2.5 \%(\mathrm{w} / \mathrm{v}) \mathrm{S}^{\circ}$. Thermoplasma acidophilum, Thermoplasma volcanium and the Thermoplasma isolates were cultivated, enriched, and cloned by plating as described by Segerer ct al. (1988).

Light microscopy and ultrastructure. Cultures were inspected by light microscopy as described by Burggraf et al. (1990). Electron microscopy was performed as described previously (König and Stetter, 1982).

DNA preparation, base composition and homology. The DNA was isolated as described by Lauerer et al. (1986). The GC-content of the DNA and DNA-DNA homology were determined as described by Segerer et al. (1988).

\section{Results and Discussion}

\section{Sampling}

During cruise SO-45B, 10 anacrobic samples (each 100 $\mathrm{ml}$ ) of shallow (depth: 30 to $82 \mathrm{~m}$; $\mathrm{T}=16$ to $20^{\circ} \mathrm{C}$ ) and deep sea (depth: 1283 to $1743 \mathrm{~m} ; \mathrm{T}=2.9$ to $3.7^{\circ} \mathrm{C}$ ) sediments were taken from box grabs, piston- and box cores at different stations north, east and south of Sumbawa and in the Komodo-Rinja region. Thirteen additional sediment samples were taken by a syringe (Stetter, 1982) within the Satonda Crater lake (depth $=0.6$ to $2 \mathrm{~m}$; $\mathrm{T}=$ $32^{\circ} \mathrm{C}$ ) and from shallow submarine hot springs (depth: 0 to $2 \mathrm{~m} ; \mathrm{T}=75$ to $96^{\circ} \mathrm{C}$ ) at the beach of Sangeang Island, about $7 \mathrm{~km}$ to the north of Kelapa village. The freshly taken samples were collected in $100 \mathrm{ml}$ storage bottles. Oxygen was reduced immediately by the addition of sodium dithionite and sodium sulfide until the redox indicator resazurin added before became colorless (Stetter, 1982). The bottles were tightly stoppered and stored at $4{ }^{\circ} \mathrm{C}$. Eight samples of sea water (depth: 14 to $2000 \mathrm{~m}$ ) werc deoxygenated as described for the sediments. In another experiment, 3-5 I of the anacrobic water samples were passed through millipore ultrafilters (pore width: 0.4 $\mu \mathrm{m}$ ) in order to concentrate the microorganisms. The filter concentrates were then stored anaerobically in tightly closed $20 \mathrm{ml}$ storage tubes.

During land expeditions, anaerobic and aerobic water and mud samples were taken from the following places (Table 1): Lake Batur, Bali: Toye Bungkah Hot Springs (TB). Dieng Plateau, Java: Kawah Sikidang Crater (KS), Kawah Candradimuka Crater (KC), and Kawah Sileri Hot Lake (SL). Tangkuban Prahu, Bandung, Java: Kawah Domas Crater (KD; altitude: $1500 \mathrm{~m}$ above sea level), Kawah Badak Crater (KB), and Kawah Djarian Crater (KDj). Ciater, Bandung, Java: Ciater Hot Springs (C). Ganung Gede, Java: Hot Waterfall (GG). All samples were

Table 1. Samples taken from hot springs and continental solfatara fields in Bali and Java

Abhreviations: $\mathrm{TB}=$ Toyc Bunkah; $\mathrm{KS}=$ Kawah Sikidang; $\mathrm{KC}$ = Kawah Candradimuka; $\mathrm{SL}=$ Kawah Sileri; $\mathrm{KD}=$ Kawah Domas; $\mathrm{KB}=$ Kawah Badak; $\mathrm{KDj}=$ Kawah Djarian; $\mathrm{C}=\mathrm{Cia}-$ ter; $\mathrm{GG}=$ Ganung Gede.

\begin{tabular}{|c|c|c|c|c|c|c|c|}
\hline \multirow{2}{*}{\multicolumn{2}{|c|}{ Designation }} & \multicolumn{2}{|c|}{ Original } & \multicolumn{2}{|c|}{ Designation } & \multicolumn{2}{|c|}{ Original } \\
\hline & & $\mathrm{pH}$ & $\begin{array}{l}\text { Temp } \\
\left({ }^{\circ} \mathrm{C}\right)\end{array}$ & & & $\mathrm{pH}$ & $\begin{array}{l}\text { Temp } \\
\left({ }^{\circ} \mathrm{C}\right)\end{array}$ \\
\hline \multirow[t]{2}{*}{$\mathrm{TB}$} & 1 & 7 & 42 & \multirow[t]{13}{*}{$\mathrm{KD}$} & 1 & 3 & 91 \\
\hline & 2 & 7 & 39 & & 2 & 2 & 94 \\
\hline \multirow[t]{17}{*}{$\mathrm{KS}$} & 1 & 1.5 & 93 & & 4 & 2 & 46 \\
\hline & 2 & 1.5 & 92 & & 5 & 2 & 86 \\
\hline & $3 *$ & 3 & 22 & & $6 *$ & 1.5 & 32 \\
\hline & $4^{*}$ & 3 & 92 & & 7 & 2 & 70 \\
\hline & 5 & 1.5 & 50 & & 8 & 4 & 94 \\
\hline & $6^{*}$ & 2 & 24 & & 9 & 3 & 50 \\
\hline & $7^{*}$ & 3 & 27 & & 10 & 3 & 50 \\
\hline & 8 & 3.5 & 51 & & 11 & 3 & 58 \\
\hline & 9 & 7 & 92 & & 12 & 3 & 93 \\
\hline & $10 \%$ & 3 & 50 & & 13 & 3 & 92 \\
\hline & 11 & 3 & 50 & & & & \\
\hline & 12 & 2.5 & 92 & \multirow[t]{4}{*}{$\mathrm{KB}$} & $1^{*}$ & 1 & 90 \\
\hline & 13 & 3.5 & 22 & & 2 & 1.5 & 68 \\
\hline & $14^{*}$ & 3.5 & 22 & & 3 & 2 & 94 \\
\hline & 15 & 5 & 92 & & & & \\
\hline & $16^{*}$ & 3 & 30 & \multirow[t]{6}{*}{$\mathrm{KDj}$} & $1^{*}$ & 3 & 92 \\
\hline & $17^{*}$ & 2 & 30 & & 2 & 3 & 93 \\
\hline \multirow{4}{*}{$\mathrm{KC}$} & 1 & 7.5 & 88 & & 4 & $\begin{array}{l}5.5 \\
1.5\end{array}$ & 92 \\
\hline & 2 & 6 & 90 & & 5 & 3.5 & 94 \\
\hline & 3 & 5 & 60 & & 6 & 1.5 & 90 \\
\hline & 4 & 7.5 & 80 & & 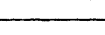 & & \\
\hline \multirow[t]{7}{*}{$\mathrm{SL}$} & $1^{*}$ & 6.5 & 55 & \multirow{2}{*}{$\mathrm{C}$} & $\begin{array}{l}1 \\
2\end{array}$ & $\begin{array}{l}3 \\
3\end{array}$ & $\begin{array}{l}42 \\
43\end{array}$ \\
\hline & 2 & 6.5 & 62 & & & & \\
\hline & $3^{*}$ & 6 & 55 & \multirow[t]{5}{*}{ GG } & 1 & 6.5 & 56 \\
\hline & $4^{*}$ & 6.5 & 40 & & 2 & 6.5 & 56 \\
\hline & $5 *$ & 3.5 & 32 & & & & \\
\hline & 6 & 5.8 & 72 & & & & \\
\hline & 7 & 3.5 & 32 & & & & \\
\hline
\end{tabular}

* aerobic sample 
carried back to the laboratory by airplane without temperature control. Growth experiments were performed at 20, $37,60,85,100$ and $110^{\circ} \mathrm{C}$ and at $\mathrm{pH} \mathrm{2,5.5,7}$ and 8.5 with various organic and anorganic substrates (e.g. Fiala and Stetter, 1986).

Archaeal isolates from sea sediments and sea water samples from the Sumbawa and Komodo-Rinja areas

In order to detect hyperthermophiles possibly existing and spreading between zones of active submarine volcanism, water and sediment samples with low ambient temperatures were incubated anaerobically at high temperatures in the presence of substrates suitable for such organisms. No hyperthermophiles could be enriched. Although only relatively few samples were taken, this result suggests that (a) these sediments did not contain significant amounts of hyperthermophiles which survived at low temperatures in the resting state and (b) the surrounding water contains less than 1 cell of hyperthermophiles per 5 liters. Probably much larger quantities of sea water within hydrothermally active areas have to be filtered (e.g. cubicmeters) in order to detect spreading cells of hyperthermophiles.

Archaeal hyperthermophiles in concentrations of up to $10^{3} / \mathrm{ml}$ sea water have recently been discovered within the open sea plume of an erupting seamount (Huber et al., 1990). When samples from the Sumbawa and KomodoRinja areas were incubated at $30^{\circ} \mathrm{C}$, mesophilic strictly anaerobic methanogenic archaea were enriched from some sediments and were purified by plating (Table 2). The physiological properties and morphology suggest that these methanogenic isolates belong to the genera Methanosarcina, Methanobacterium, and Methanolobus (Balch et al., 1979; König and Stetter, 1982). Methanolobus is an obligate methylotroph which has so far been isolated only from a black marine sediment in Tindari, Sicily (König and Stetter, 1982). Our results suggest that it may be common in marine sediments. A novel highly irregular ("leach" shaped) methanogen from Lake Satonda was up to now obtained only in syntrophic mixed culture with Clostridia.

Hyperthermophilic archaeal and bacterial isolates from the shallow submarine hot springs at the beach of Sangeang Island

From sample SG7 (original temp. $=90^{\circ} \mathrm{C}$ ), a new coccoid strictly anaerobic heterotrophic hyperthermophilic archaeon was isolated under anaerobic growth conditions at $90{ }^{\circ} \mathrm{C}$ in artificial sea water (SME; Stetter et al., 1983) supplemented with yeast extract $(0.1 \% \mathrm{w} / \mathrm{v})$ and elemental sulfur. The coccoid cells of the isolate measure about 0.5 to $2 \mu \mathrm{m}$ in diameter, occur mainly in pairs (Fig. 1) and are

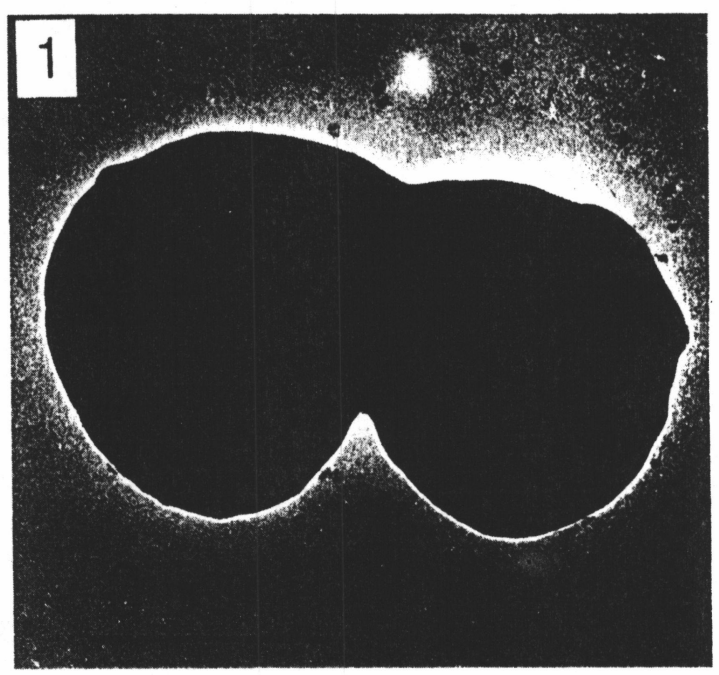

Fig. 1. Dividing cell of the hyperthermophilic archaeal isolate SG7. EM micrograph, negative staining.

Table 2. Mesophilic methanogenic archaea isolated from sea sediments with low original temperatures of the Sumbawa and Komodo Rinja areas

\begin{tabular}{|c|c|c|c|c|c|}
\hline Sample & Station & $\begin{array}{l}\text { Water } \\
\text { depth }(m)\end{array}$ & $\begin{array}{l}\text { Original } \\
\text { temperature }\left({ }^{\circ} \mathrm{C}\right)\end{array}$ & Description & Isolate \\
\hline FS-1 & $101-2$ & 1735 & 2.9 & $\begin{array}{l}\text { greyish-green } \\
\text { sediment }\end{array}$ & Methanosarcina sp. \\
\hline FS-6 & $107-2$ & 82 & 16 & $\begin{array}{l}\text { greyish sediment } \\
\text { with concretions }\end{array}$ & Methanolobus sp. \\
\hline FS-7 & $113-1$ & 45 & 19 & $\begin{array}{l}\text { greyish sediment } \\
\text { banded hematite }\end{array}$ & Methanolobus sp. \\
\hline FS-14 & $\begin{array}{l}\text { Satonda Crater Lake, } \\
\text { Stat. } 16\end{array}$ & 0 & 27 & black mud in spring & Methanolobus sp. \\
\hline FS-15 & $\begin{array}{l}\text { Satonda Crater Lake, } \\
\text { embarkation site }\end{array}$ & 2 & 32 & black sediment & Methanolobus sp. \\
\hline FS-15a & $\begin{array}{l}\text { Satonda Crater Lake } \\
\text { bottom }\end{array}$ & 60 & 29 & $\begin{array}{l}\text { black sediment, } \\
\text { contains } \mathrm{H}_{2} \mathrm{~S}\end{array}$ & $\begin{array}{l}\text { Methanosarcina sp. } \\
\text { enrichment culture: novel } \\
\text { irregular leach-shaped } \\
\text { methanogen }\end{array}$ \\
\hline
\end{tabular}


motile by polar monotrichous flagellation. Complex organic nutrients like yeast extract, peptone, meat extract and tryptone serve as energy source for growth. Elemental sulfur is not essential for growth. However, in the presence of $\mathrm{S}^{\circ}, \mathrm{H}_{2} \mathrm{~S}$ is formed instead of $\mathrm{H}_{2}$ (up to $3 \mu$ moles $/ \mathrm{ml}$ culture medium). The new isolate grows between 46 and $96^{\circ} \mathrm{C}$ with an optimum at around $88^{\circ} \mathrm{C}$. Growth occurs in the presence of 0.7 to $8 \% \mathrm{NaCl}$ at a $\mathrm{pH}$ between 5.0 and 8.0. The DNA of isolate SG7 shows a GC-content of 40 mol\% and is therefore similar to Thermococcus litoralis (38 mol\% GC; Neuner et al., 1990) and different to Thermococcus celer (56 mol\% GC; Zillig et al., 1983) and Pyrococcus furiosus $(37 \mathrm{~mol} \%$ GC; Fiala and Stetter, 1986). By DNA-DNA hybridization (Table 3) a specific phylogenetic relationship of SG7 with Thermococcus litoralis was detected, indicating that the Sangeang isolate belongs to the same species which has so far been found only in Italy (Neuner et al., 1990).

Table 3. DNA homology (\%) between the new archaeal isolate SG7, Thermococcus celer, Thermococcus litoralis, and Pyrococcus furiosus

\begin{tabular}{lcccc}
\hline $\begin{array}{l}\text { Source of filter-bound } \\
\text { DNA }\end{array}$ & \multicolumn{4}{c}{$\begin{array}{c}\text { \% Homology with the following } \\
\text { sources of }\end{array}$} \\
\cline { 2 - 5 } & $\begin{array}{l}\text { T2 } \\
\text { Tc.labeled DNA }\end{array}$ \\
\hline celer & $\begin{array}{l}\text { Tc. } \\
\text { litoralis }\end{array}$ & $\begin{array}{l}\text { Pc. } \\
\text { furiosus }\end{array}$ & $\begin{array}{l}\text { Isolate } \\
\text { SG7 }\end{array}$ \\
\hline Thermococcus celer & $(100)$ & 2 & 6 & 5 \\
Thermococcus litoralis & 6 & $(100)$ & 2 & 85 \\
Pyrococcus furiosus & 3 & 4 & $(100)$ & 7 \\
Isolate SG7 & 6 & 88 & 12 & $(100)$ \\
\hline
\end{tabular}

From samples SG1 and SG7 (both with original temperatures of $90^{\circ} \mathrm{C}$ ), rod-shaped cells with a characteristic outer sheath could be enriched and isolated anacrobically at $85^{\circ} \mathrm{C}$ in Thermotoga medium (Huber et al., 1986 b). Both isolates turned out to be bacterial hyperthermophiles belonging to the genus Thermotoga. They represent a new species as indicated by the low DNA homology with the type strain Thermotoga maritima DSM 3109 and with some other still undescribed Thermotoga isolates from elsewhere (Table 4). In contrast to the other Thermotoga

Table 4. DNA homology ( $\%)$ between Thermotoga maritima, Thermotoga neapolitana, and some recent Thermotoga isolates and isolates SG1 and SG7 from Sangeang

\begin{tabular}{lcc}
\hline $\begin{array}{l}\text { Source of filter-bound } \\
\text { DNA }\end{array}$ & $\begin{array}{c}\% \text { Homology with the following } \\
\text { sources of }{ }^{32} \text { P-labcled DNA }\end{array}$ \\
\cline { 2 - 3 } & Isolate SG1 & Isolate SG7 \\
\hline Thermotoga maritima & 15 & 13 \\
Thermotoga neapolitana & 55 & 40 \\
Isolate RQ 2 (Azores) & 12 & 15 \\
Isolate RQ 7 (Azores) & 55 & 38 \\
Sangeang isolate SG1 & $(100)$ & 82 \\
\hline
\end{tabular}

strains, the Indonesian isolates grow in aggregates (up to 15 cells) and can therefore be casily distinguished.

\section{Methanogenic isolates from the Toye Bungkah hot springs, Bali}

From anaerobic samples taken from the black mud of the two ponds at the hot spring of Toye Bungkah, Lake Batur, Bali (TB 1, 2; Table 1), a member of the genus Methanobacterium (Balch et al., 1979) was isolated from the pond close to the origin of the spring (TB 1). From the second pond (TB 2), a Methanobacterium sp. similar to TB 1 and a Methanosarcina sp. were isolated. The determination of their exact taxonomic position is in progress.

Hyperthermophilic and thermophilic archaea and bacteria isolated from solfatara fields at the Dieng Platean and Tangkuban Prabu, Java

In Java, hot springs and solfatara fields at the Dieng Plateau, Tangkuban Prahu, Ciater, and Ganung Gede (Table 1) were investigated for thermophilic anaerobic and acrobic archaea and bacteria (Table 5). At the Dieng Plateau, samples were taken from three different types of solfatara fields: (a) Kawah Sikidang with strongly acidic water- and mudholes of up to boiling temperatures, (b) Kawah Candradimuka with neutral to slightly acidic almost boiling hot springs, and (c) Kawah Sileri with neutral to slightly acidic muddy blackish water with temperatures around $65^{\circ} \mathrm{C}$. Within the Tangkuban Prahu area, samples were collected at three different solfatara fields mainly with strongly acidic $\mathrm{pH}$ and very high temperatures: (a) Kawah Domas with many strongly gassed water- and mudholes, (b) Kawah Badak with many fumaroles and very few tiny waterholes, and (c) Kawah Djarian situated within a rain forest with trees decomposing within boiling holes of sulfur mud. In addition, samples were taken from an acidic warm spring in Ciater and from a hot waterfall with neutral $\mathrm{pH}$ at Ganung Gede.

No archaeal isolates were obtained from the samples of Ciater and Ganung Gede. From the acidic hot springs and mudholes at the Dieng Plateau and at Tangkuban Prahu, members of the genus Acidianus were isolated in Allen's medium (Allen, 1959; Table 5). These are chemolithoautotrophic facultative aerobes, growing by oxidation or reduction of elemental sulfur, depending on the redox potential (Segerer et al., 1985; Segerer et al., 1986 a). All isolates grow at temperatures of up to $96^{\circ} \mathrm{C}$ and are by this feature similar to the type species Acidianus infernus (isolated in Italy). Again from the acidic hot springs of this area, many Sulfolobus enrichment cultures could be obtained aerobically on $\mathrm{S}^{\circ}$ and yeast extract (data not shown), which were not further characterized up to now. From a hot acidic waterhole (KB 1; Table 5) in Kawah Badak, a novel coccoid Sulfolobus-shaped (Brock, 1978) archaeal metal mobilizer was isolated, suitable for microbial leaching of sulfidic ores at high temperatures. The organism grows chemolithoautotrophically at temperatures up to $80^{\circ} \mathrm{C}$ with pyrite, chalcopyrite and sphalerite as energy sources. After 1 week at $80^{\circ} \mathrm{C}$, cell densities of $10^{8} / \mathrm{ml}$ are obtained in the laboratory, indicating very vig- 
Table 5. Hyperthermophilic and thermophilic archaeal and bacterial isolates from hot springs and mudholes in Java

\begin{tabular}{|c|c|c|c|c|}
\hline Area & $\begin{array}{l}\text { Name of solfatara } \\
\text { field }\end{array}$ & $\begin{array}{l}\text { Isolates from } \\
\text { samples }\end{array}$ & Genus & $\begin{array}{l}\text { Growth } \\
\text { up to }\left({ }^{\circ} \mathrm{C}\right)\end{array}$ \\
\hline \multirow{3}{*}{$\begin{array}{l}\text { Dieng } \\
\text { Plateau }\end{array}$} & Kawah Sikidang & $\begin{array}{l}\text { KS } 1,2,12,15 \\
\text { KS } 9,15 \\
\text { KS } 9,15 \\
\text { KS } 5,8,11\end{array}$ & $\begin{array}{l}\text { Acidianus infernus (?) } \\
\text { Thermoproteus } \mathrm{sp} . \\
\text { Desulfurococcus } \mathrm{sp} . \\
\text { Thermoplasma } \mathrm{sp} .\end{array}$ & $\begin{array}{l}96 \\
96 \\
96 \\
67\end{array}$ \\
\hline & $\begin{array}{l}\text { Kawah Candra- } \\
\text { dimuka }\end{array}$ & $\begin{array}{l}\text { KC } 1,2,4 \\
\text { KC } 1,2 \\
\text { KC } 4\end{array}$ & $\begin{array}{l}\text { Thermoproteus } \\
\text { Desulfurococcus } \\
\text { novel unnamed } \mathrm{H}_{2} / \mathrm{NO}_{3}{ }^{-} \text {- } \\
\text { autotrophic bacterium }\end{array}$ & $\begin{array}{l}96 \\
96 \\
80\end{array}$ \\
\hline & Kawah Sileri & $\begin{array}{l}\text { SL. } 7 \\
\text { SL } 3\end{array}$ & $\begin{array}{l}\text { Thermoplasma sp. } \\
\text { vibrio-shaped new bac- } \\
\text { terial metal mobilizer }\end{array}$ & $\begin{array}{l}67 \\
50\end{array}$ \\
\hline \multirow{3}{*}{$\begin{array}{l}\text { Tangkuban } \\
\text { Prahu }\end{array}$} & Kawah Domas & $\begin{array}{l}\text { KD } 1,2,3,5 \\
\text { KD } 3,5,7\end{array}$ & $\begin{array}{l}\text { Acidianus infernus (?) } \\
\text { Thermoplasma sp. }\end{array}$ & $\begin{array}{l}96 \\
67\end{array}$ \\
\hline & Kawah Badak & $\begin{array}{ll}\mathrm{KB} & 3 \\
\mathrm{~KB} & 1\end{array}$ & $\begin{array}{l}\text { Acidianus infernus (?) } \\
\text { Coccoid novel archaeal } \\
\text { metal mobilizer }\end{array}$ & $\begin{array}{l}96 \\
80\end{array}$ \\
\hline & Kawah Djarian & $\begin{array}{l}\text { KDj } 3 \\
\text { KDJ 3, } 5\end{array}$ & $\begin{array}{l}\text { Acidianus infernus (?) } \\
\text { Thermoproteus }\end{array}$ & $\begin{array}{l}96 \\
96\end{array}$ \\
\hline
\end{tabular}

orous growth on ores compared to other thermophilic ore leachers (Huber et al., 1986 a). A moderately thermophilic so far unknown acidophilic vibrio-shaped ore leaching bacterium was isolated from sample SL3 (table 5). It grows optimally at $45^{\circ} \mathrm{C}$ ( 5 hours doubling time) in the presence of sphalerite and pitch blend or, alternatively, yeast extract (E. Drobner and K. O. Stetter, unpublished).

The less acidic to neutral hot samples contained anaerobic, sulfur respiring, rod shaped organisms, growing at $96^{\circ} \mathrm{C}$ in Allen's medium (Allen, 1959) in the presence of yeast extract, peptone and elemental sulfur. Elemental sulfur was replaceable by thiosulfate $(0.1 \% \mathrm{w} / \mathrm{v})$. The rods exhibit true branching and terminal spherical bodies ("golf clubs") which are typical for members of the genus Thermoproteus (Zillig et al., 1981). In the same enrichment cultures, also coccoid archaea were found, thriving organotrophically by $\mathrm{S}^{\circ}$-respiration at temperatures up to $96^{\circ} \mathrm{C}$ (Table 5). Most likely, they belong to the genus Desulfurococcus (Zillig et al., 1982).

From locations with strongly acidic $\mathrm{pH}$ and moderately hot temperatures $\left(50^{\circ} \mathrm{C}\right)$, cell wall-less (Fig. 2) highly irregular coccoid thermoacidophilic archaea growing up to $67^{\circ} \mathrm{C}$ could be enriched in Darland's medium (Darland et al., 1970). They were cloned by plating on medium solidified by $10 \%$ starch. After 4 days of incubation at $60^{\circ} \mathrm{C}$ in the presence of a $\mathrm{CO}_{2}$ /air atmosphere $(50: 50)$, small $(0.2 \mathrm{~mm} \varnothing)$ "friedegg"-shaped colonies became visible (Fig. 3). Very surprisingly, cell extracts of the isolates showed serological cross-reaction with antibodies prepared against the histone-like protein of Thermoplasma acidophilum (DSM 1728), indicating a phylogenetic relationship of the isolates to the genus Thermoplasma (Stein and Searcy, 1978). This genus had been described to exist only within smoldering coal refuse piles (Darland et al., 1970; Brock, 1978).

Similar to other Thermoplasma isolates which we had obtained recently from solfataric fields in Italy, Yellowstone National Park, the Azores, and Iceland, the Indonesian isolates are different from the type species Thermoplasma acidophilum and exhibit a GC-content of their DNA of $40 \mathrm{~mol} \%$ (instead of $46 \mathrm{~mol} \%$ for T.a.; Segerer et al., 1988). In DNA-DNA hybridization experiments all 7 Indonesian isolates turned out to be genetically identical (100\% DNA homology; data not shown), while they exhi-

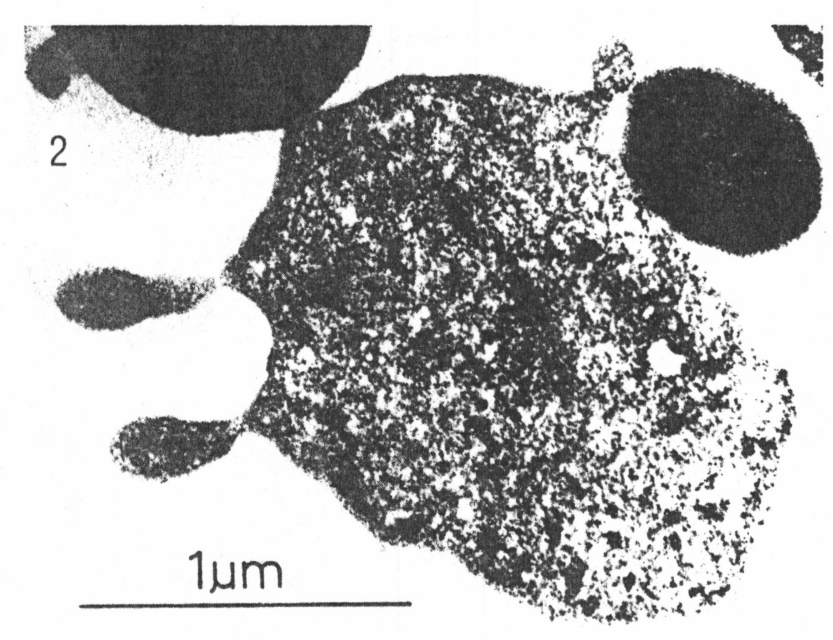

Fig. 2. Cell of the Thermoplasma isolate KD3. EM micrograph, ultrathin section. 


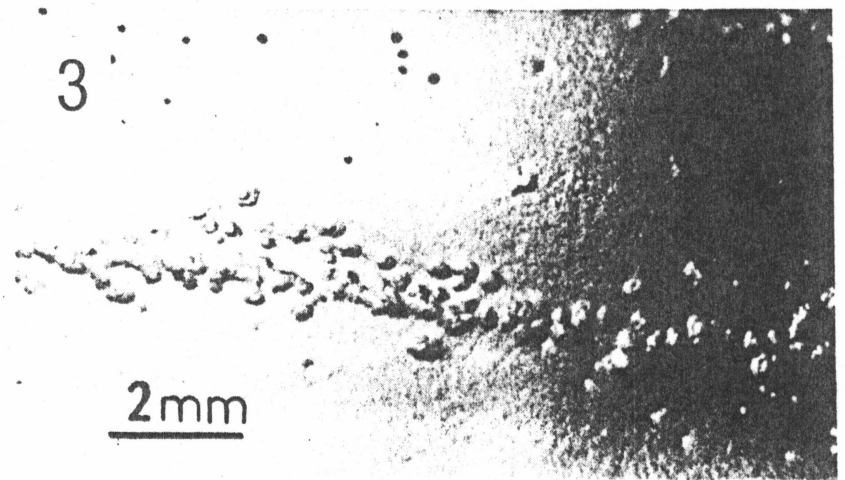

Fig. 3. Colonies of the Thermoplasma isolate KD3 on a starch plate.

bited no significant homology ( 7 to $12 \%$; Segerer et al., 1988) with Thermoplasma acidophilum and the isolates from the other solfataric fields. Therefore, the Indonesian isolates represent a so far unknown genotype of Thermoplasma. Phenotypically, they can be distinguished from the type species T. acidophilum also by physiological properties, for example their lower minimal and higher maximal growth temperatures and their higher salt tolerance (Table 6). However, in contrast to their genetic difference, no separating features were found so far between them and some of the Thermoplasma isolates from other solfataric fields which had been described as Thermoplasma volcanium (Table 6; Segerer et al., 1988). Similar to both type strains, the Indonesian Thermoplasma isolates are organotrophic facultative anaerobes (Segerer et al., 1986 b). The recent isolation of members of Thermoplas$m a$ in Indonesia and other countries demonstrates, that solfatara fields are the (most likely primary) biotope of this group of archaea (Segerer et al., 1988). The ability to grow within the mesophilic temperature range and the isolation of strain SL 7 from a tropical swamp (original temperature: $32^{\circ} \mathrm{C}$ ) in Kawah Sileri show that tropical swamps and similar biotopes, e.g. self-heating organic waste, may be further biotopes for these acidophilic archaca.

From the hot mud sample KC 4, a novel rod-shaped flagellated Gram-negative bacterium (Fig. 4) was obtained on medium 1 (Balch et al., 1979) at $75^{\circ} \mathrm{C}$. The isolate (KC

Table 6. Physiological properties of Thermoplasma acidophilum (DSM 1728), Thermoplasma volcanium (DSM 4299), and the Indonesian Thermoplasma isolate KD3

\begin{tabular}{|c|c|c|c|c|c|c|c|c|c|c|}
\hline \multirow[t]{2}{*}{ Strain } & \multicolumn{3}{|c|}{ Growth temperature $\left({ }^{\circ} \mathrm{C}\right)$} & \multicolumn{3}{|c|}{$\mathrm{pH}$ for growth } & \multicolumn{3}{|c|}{$\mathrm{NaCl}$ requirement $(\%)$} & \multirow{2}{*}{$\begin{array}{l}\text { GC content } \\
(\mathrm{mol} \%)\end{array}$} \\
\hline & $\min$ & opt & $\max$ & $\min$ & opt & $\max$ & $\min$ & opt & $\max$ & \\
\hline $\begin{array}{l}\text { Thermoplasma acidophilum } \\
\text { DSM } 1728\end{array}$ & 45 & 59 & 63 & 0.8 & 2 & 4 & 0.01 & 0.25 & 2 & 46 \\
\hline $\begin{array}{l}\text { Thermoplasma volcanium } \\
\text { DSM 4299* }\end{array}$ & 32 & 59 & 67 & 0.8 & 2 & 4 & 0.01 & 0.25 & 2 & 38 \\
\hline Isolate KD3 DSM 4300 & 32 & 59 & 67 & 0.8 & 2 & 4 & 0.01 & 0.25 & 4 & 40 \\
\hline
\end{tabular}

* isolated from Vulcano, Italy

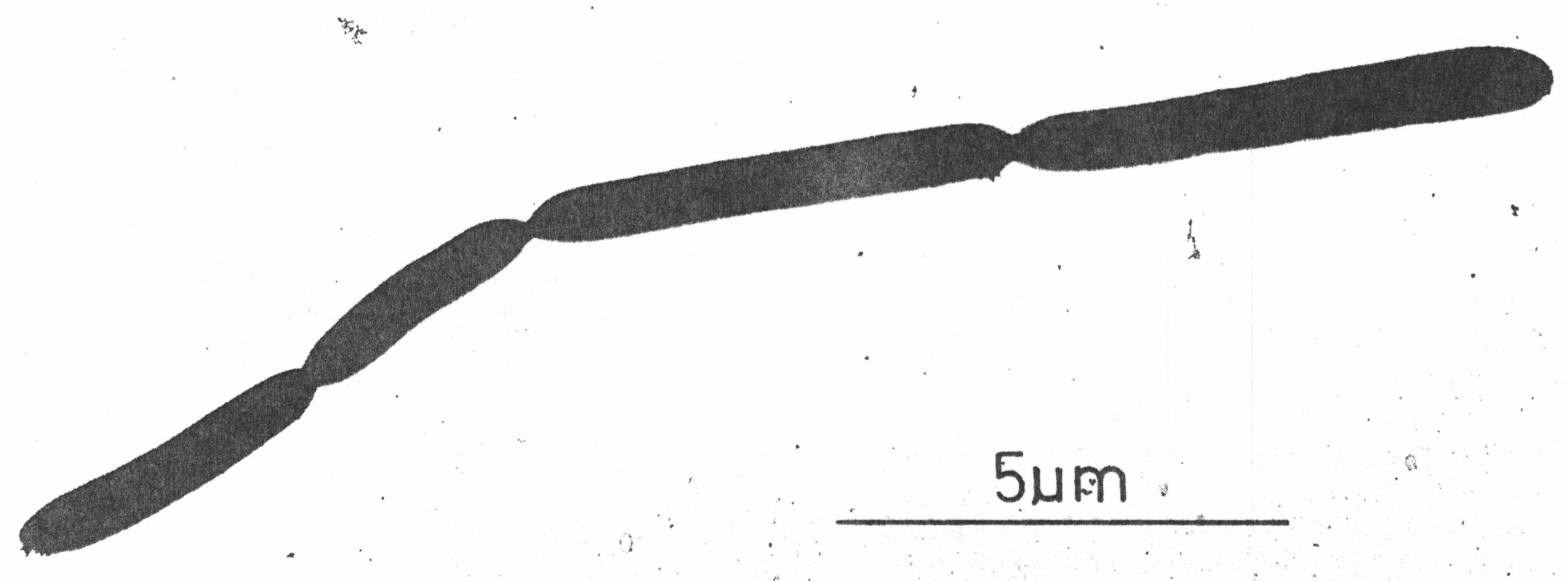

Fig. 4. Cells of isolate KC4. EM micrograph, negative staining. 
4; Table 5) is a strictly chemolithoautotrophic anacrobe, growing in mineral medium in the presence of molecular hydrogen, nitrate $(0.1 \% \mathrm{w} / \mathrm{v})$ and $\mathrm{CO}_{2}$ at ncutral $\mathrm{pH}$ and temperatures of up to $80^{\circ} \mathrm{C}$. Stoichiometric amounts of ammonia are formed during growth (not shown), indicating that the new organism is gaining energy by the so far unknown $\mathrm{H}_{2} / \mathrm{NO}_{3}{ }^{-}$chemolithoautotrophy. This way of nutrition is made possible by the relatively high nitrate content of up to $5 \mu$ moles/l present in this type of hot springs (G. Liebezeit, pers. comm.). Batch cultures (50 I) of isolate $\mathrm{KC} 4$ were grown in an enamel-protected fermentor (yield: $0.5 \mathrm{~g}$ wet weight/l). Phylogenetically the novel isolate trees deeply among the bacteria and does not seem to belong to any known phylum as indicated by $16 \mathrm{~S}$ rRNA sequence comparisons (C. R. Woese, pers. comm.).

Acknowledgements. We wish to thank D. Fisma, W. u. Haugwitz, S. Kempe, A. Masduki, J. Schilling and A. Zünkerl for essential assistance in obtaining samples and $G$. Liebezeit for water analyses. This work was supported by grants from the Bundesministerium für Forschung und Technologie, Bonn, to E.T.D. and from the Deutsche Forschungsgesellschaft, Schwerpunkt: Methanogene Bakterien to K.O.S. and from Gist Brocades, Delft to B.E.J. and K.O.S.

\section{References}

Allen. M. B.: Studies with Cyanidium caldarimm, an anomalously pigmented chlorophyte. Arch. Mikrobiol. 32, 270-277 (1959)

Balch, W. E., Fox, G. E., Magrum, L. J., Woese, C. R., Wolfe, R. S.: Methanogens: Reevaluation of a unique biological group. Microbiol. Rev. 43, 260-296 (1979)

Brock, T. D.: Thermophilic microorganisms and life at high temperatures. Berlin-Heidelberg-New York, Springer-Verlag, 1978

Burggraf, S., Fricke, H., Neuner, A., Kristiansson, J., Rouvier, P., Mandelko, L., Woese, C. R., Stetter, K. O.: Methanococcus igneus sp. nov., a novel hyperthermophilic methanogen from a shallow submarine hydrothermal system. Appl. Microbiol. 13, 263-269 (1990)

Darland, G., Brock, T. D., Samsonoff, W., Conti, S. F.: A thermophilic, acidophilic Mycoplasma isolated from a coal refuse pile. Science 170, 1416-1418 (1970)

Fiala, G., Stetter, K. O.: Pyrococcus furiosus sp. nov. represents a novel genus of marine heterotrophic archacbacteria growing optimally at $100^{\circ} \mathrm{C}$. Arch. Microbiol. $145,56-61$ (1986)

Huber, G., Huber, H., Stetter, K. O.: Isolation and characterization of new metal-mobilizing bacteria. Biotech. Biocng. Symp. $16,239-251$ (1986a)

Huber, R., Langwortby, T. A., König, H., Thomm, M., Woese, C. R., Sleytr, U. B., Stetter, K. O.: Thermotoga maritima sp. nov. represents a new genus of unique extremely thermophilic eubacteria growing up to $90^{\circ} \mathrm{C}$. Arch. Microbiol. 144, $324-333$ (1986 b)

Huber, R., Stoffers, P., Cheminee, J. L., Richnow, H. H., Stetter, K. O.: Hyperthermophilic archaebacteria within the crater and open-sea plume of erupting Macdonald seamount. Nature 345, 179-182 (1990)

Jannasch, H. W., Huber, R., Belkin, S., Stetter, K. O.: Thermotoga neapolitana sp. nov. of the extremely thermophilic, cubacterial genus Thermotoga. Arch. Microbiol. 150, 103-104 (1988)
Kïnig, H., Sletter, K. ().: Isolation and characterization of Methanolobus tindarius sp. nov., a coccoid methanogen growing only on methanol and methylamines. Zbl. Bakt. Hyg., I. Abt. Orig. C 3, 478-490 (1982)

Laucrer, G., Kristjansson, J. K., Langworthy, T. A., König, H., Stetter, K. O.: Methanolobus sociabilis sp. nov., a second species within the Methanothermaceae growing at $97^{\circ} \mathrm{C}$. System. Appl. Microbiol. 8, 100-105 (1986)

Neuner, A., Jannasch, H. W., Belkin, S., Stetter, K. O.: Thermococcus litoralis sp. nov.: A new species of extremely thermophilic marine archacbacteria. Arch. Microbiol. 153, $205-207(1990)$

Segerer, A., Stetter, K. O., Klink, F.: Two contrary modes of chemolithotrophy in the same archaebacterium. Nature 313, 787-789 (1985)

Segerer, A., Neuner, A., Kristiansson, J. K., Stetter, K. O.: Acidiamus infernus gen. nov., sp. nov., and Acidianus brierleyi comb. nov.: Facultatively aerobic, extremely acidophilic thermophilic sulfur-metabolizing archaebacteria. Int. J. System. Bact. 36, 559-564 (1986:a)

Segerer, A., Stetter, K. O., Klink, F.: Novel facultatively aerobic sulfur-dependent archacbacteria, p. 430. In: Archacbacteria '85 (O. Kandler and W. Zilling, eds.), Stuttgart-New York, G. Fischer Verlag, 1986b

Segerer, A., Languorthy, T. A., Stetter, K. O.: Thermoplasma acidophilum and Thermoplasina volcanium sp. nov. from solfatara ficlds. System. Appl. Microbiol. 10, 161-171 (1988)

Stein, D. B., Searcy, D. G.: Physiologically important stabilization of DNA by a prokaryotic histone-like protein. Science 202, 219-221 (1978)

Stetter, K. O.: Ultrathin mycelia-forming organisms from submarine volcanic areas having an optimum growth temperature of $10.5^{\circ} \mathrm{C}$. Nature $300,258-260$ (1982)

Stetter, K. O.: Diversity of extremely thermophilic archaebacteria, pp. 39-74. In: Thermophiles: General, Molecular and Applied Microbiology (T. D. Brock, ed.), New York-LondonSydney-Toronto, J. Wiley \& Sons, Inc., 1986

Stetter, K. O., Zillig, W.: Thermoplasma and the thermophilic sulfur-dependent archaebacteria, pp. 85-170. In: The Bacteria, Vol. VIII (R.S. Wolfe and C. R. Woese, eds.). New York, Academic Press, 1985

Stetter, K. O., König, H., Stackebrandt, E.: Pyrodictium gen. nov., a new genus of submarine disc-shaped sulphur reducing archacbacteria growing optimally at $105^{\circ} \mathrm{C}$. System. Appl. Microbiol. 4, 535-551 (1983)

Stetter, K. O., Lauerer, G., Thomm, M., Neuner, A.: Isolation of extremely thermophilic sulfate reducers: Evidence for a novel branch of archaebacteria. Science 236, 822-824 (1987)

Stetter, K. O., Fiala, G., Huber, G., Huber, R., Segerer, A.: Hyperthermophilic microorganisms. FEMS Microbiol. Rev. 75, 117-124 (1990)

Windberger, E., Huber, R., Trincone, A., Fricke, H., Stetter, K. O.: Thermotoga thermarum sp. nov. and Thermotoga neapolitana occurring in African continental solfataric springs. Arch. Microbiol. 151, 506-512 (1989)

Woese, C. R.: Bacterial evolution. Microbiol. Rev. 51, 221-271 (1987)

Woese, C. R., Magrum, L. J., Fox, G. E.: Archaebacteria. J. Molec. Evol. 11, 245-252 (1978)

Woese, C. R., Kandler, ()., Wheelis, M. L.: Towards a natural system of organisms: Proposal for the domains archaea, bacteria and eucarya. Proc. Natl. Acad. Sci. USA 87, 4576-4579 (1990)

Zillig, W., Stetter, K. O., Schäfer, W., Janecovic, D., Wunderl, S., Holz, I., Palm, P.: Thermoproteales: A novel type of extremely thermoacidophilic anacrobic archacbacteria isolated from 
Icelandic solfataras. Zbl. Bakt. Hyg., I. Nht. Orig. C, 2, Zillig, W., Holz, I., Janecovic, D., Schäfer, D., Reiter, W. D.: The 205-227 (1981)

Zillig, W., Stetter, K. O., Prangishuilli, D., Schäfer, W., Wunderl, S., Janecovic, D., Holz, I., Palm, P.: Desulfurococcaceac, the archacbacterium Thermococcus celer represents a novel genus second family of the extremely thermophilic, anacrobic, sulfurwithin the thermophilic branch of the archaebacteria. System. respiring Thermoproteales. Zhl. Bakt. Hyg., I. Abt. Orig. C.3. Appl. Microhiol. 4, 88-94 (1983)

Professor Dr. Karl O. Stetter, Universität Regensburg, Universitätsstr. 31, D-8400 Regensburg 